\title{
11 The Early American Novel and Sentimentalism
}

\begin{abstract}
This essay proposes three ways of reading the first sentimental American novels from a transatlantic perspective. The first, most established account tells the story of American novelists' transformations of Richardsonian literary formulae and negotiations of Lockean empiricism and liberalism. Inspired by the transnational turn in American Studies, the second narrative expands the scope of inquiry as it traces early sentimental fictions' imbrication in a transatlantic colonial and post-colonial network that significantly transcends English-American relations to include the Western hemisphere, Europe, and Africa. My third reading draws on the systemstheoretic notion of "functional differentiation" to explore convergences between eighteenth-century European reflections on art and sensuous cognition under the heading of 'aesthetics' and early American novelistic production. My second section focuses on a little-studied sentimental novel, William Hill Brown's posthumously published Ira and Isabella (1807), to test the strengths and limitations of my three transatlantic reading strategies.
\end{abstract}

Key Terms: Sentimental novel, early republic, aesthetics, systems theory, transnational turn

\section{Transatlantic Perspectives on the Early American Sentimental Novel: Approaches, Theories, Concepts}

Revisiting early American sentimental novels such as William Hill Brown's The Power of Sympathy (1789) and Hannah Webster Foster's The Coquette (1797) from a transatlantic perspective allows us to tell thoroughly familiar, new, and unexpected stories. ${ }^{1}$ The thoroughly familiar narrative traces the American transformation of English literary models, epistemological frameworks, and political ideas. I tell this story in the

1 Sections 1.3 and 2 of this essay draw and elaborate on ideas developed in two previous publications of mine: "Book and Wax: Two Early American Media of Deception" (2012) and the first third of Askin, Hägler, and Schweighauser's “Introduction: Aesthetics after the Speculative Turn” (2014). I am grateful to Daniel Allemann for his diligent proofreading and formatting of this essay. 
first part of this essay's initial section (1.1). My second part (1.2) resituates these novels in the spirit of the relatively new 'transnational turn' in American Studies to inquire into their post-colonial and colonial investments in an Atlantic world that connects Europe, North America (including the Caribbean), South America, and Africa. The third part of this section (1.3) introduces a less familiar, perhaps unexpected narrative: that of a transatlantically shared concern with the nature of art and sensuous cognition that preoccupied both the first American sentimental writers and contemporaneous European aestheticians. My second section (2) turns to William Hill Brown's posthumously published novel Ira and Isabella (1807) to probe the uses and limitations of these three transatlantic perspectives on the first sentimental writings published in North America.

\subsection{British Models and American Transformations}

Like other subgenres of the early American novel, the first sentimental novels are modeled on British precursors, chief among them Samuel Richardson's Pamela (1740-1741), his Clarissa (1747-1748), and Laurence Sterne's A Sentimental Journey (1768). These British novels are themselves part of a larger body of European sentimental writing that includes bestselling works such as Antoine-François Prévost's Manon Lescaut (1731), Jean-Jacques Rousseau's Julie (1761), and Johann Wolfgang von Goethe's Die Leiden des jungen Werthers (1774). Thus, when we think of early American sentimental novels in a transatlantic context, we need to remind ourselves that this context extends well beyond cultural relations between Britain and the United States. At the same time, it is no surprise that early studies of the first American novels such as Herbert Ross Brown's The Sentimental Novel in America (1940), Alexander Cowie's The Rise of the American Novel (1948), and Henri Petter's The Early American Novel (1971) focused on British-American relations. After all, the book which most critics consider the first American novel, The Power of Sympathy, was published only one year after the ratification of the U.S. Constitution in 1788. This cries out for a literary-historical narrative that connects the emergence of the American novel with that of the nation-state that came out of the American Revolution. It is this nexus between literary and national independence that prompts Herbert Ross Brown to decry what he considers early sentimental novels' excessive reliance on British models:

The most striking manifestation of Richardson's influence is to be seen in the appaling popularity of the seduction motif with its seemingly limitless possibilities for sentimental and sensational scenes. Here, in a more or less Americanized setting, are to be encountered all the famous Richardsonian episodes from Squire B.'s tricks of low cunning to the superior ruses of Lovelace. Repeated with wearisome monotony are the fatal elopement by carriage, the abduction of the heroine from a masquerade ball, the victim's last will and testament with tearful remembrances for her friends and soft impeachments for her foes, and, finally, the lingering death from a broken 
heart - all calculated to inspire that 'handkerchiefly feeling' which had become a requisite of popular fiction. $(1940,44)$

Brown finds much that is wrong with the early sentimental novel, most notably its popularity, its use of clichéd motifs and tropes, and its sentimentality, which, in his usage, we can gloss as "affectation of sensibility, exaggerated insistence upon the claims of sentiment” (OED, sense a.). Yet it is his censure of the novels' repetitiveness ("Repeated with wearisome monotony") that takes us to the heart of his complaint. Brown's critique here aims not only at what he considers these novels' inherent aesthetic flaws but also at their imitation of a British model. This literature, which manages to give us but "a more or less Americanized setting," is not American enough. In this account, then, the transatlantic origins of the early American sentimental novel are a post-colonial liability.

Only one year after The Sentimental Novel in America was published, a much more influential literary-historical narrative appeared that would consolidate Brown's judgment for over a generation of literary critics. F. O. Matthiessen's The American Renaissance: Art and Expression in the Age of Emerson and Whitman (1941) suggests that it was only around the 1830s that a genuinely American literary tradition was born. While Matthiessen's exceptionalist narrative of the birth of American literature out of a spirit of national and cultural independence attributed patriotic significance and cultural weight to the works of a small selection of nineteenth-century writers, it also relegated the preceding generation to a pre-history of truly American literature. This kind of story about the early American novel, which already informs The Sentimental Novel in America and is powerfully consolidated by Matthiessen, had a profound impact on future critics. Witness the beginning of Cowie's The Rise of the American Novel (1948), which was published seven years after The American Renaissance:

For the dearth of good American literature during the first 150 or 200 years of the white history of the country, apology is needed less than explanation. A new nation, like a new-born baby, requires time before its special characteristics become discernible. [...] [G]enerations had to pass before the emergence of those particular traits known as American. $(1948,1)$

Cowie follows Matthiessen in situating literary production before the American Renaissance in a cultural moment that did not allow for the expression of America's "special characteristics" and "particular traits" because it had not fully emerged from "the parental control of Great Britain" $(1948,1)$ yet. Cowie diagnoses "a definite lag between English practice and American imitation" which ensured that "[b]efore 1820 [...] there were no novelists of real stature" (1948, 3-4). He does make exceptions - most prominently for Charles Brockden Brown, Hugh Henry Brackenridge, and James Fenimore Cooper - but the early sentimental novelists are in for some of Cowie's harshest verdicts. While Susanna Rowson's Charlotte Temple is credited with "real merit" (Cowie 1948, 15), he declares that The Power of Sympathy "is readable 
only because it is reasonably brief: in a long novel the author's over-wrought rhetoric and moral rant would have been intolerable" $(1948,11)$. In a similar vein, he decries that The Coquette "fills the interims of the action with the same sort of sentiment, didacticism, and stuffy analysis of the 'heart' that clogs Richardson's Clarissa" (1948, 16). In such accounts of literary history written under Matthiessen's spell, we find that critiques of sentimentality, aesthetic weakness, and derivativeness go hand in hand. Fittingly, Winfried Fluck (2000) calls these accounts the "infancy thesis" of the early American novel. Matthiessen's book, then, had two major impacts on early assessments of the first American novels: it simultaneously situated them firmly in an anglophone transatlantic context of cultural exchange and devalued them as still too trapped in the colonial past.

One and a half decades after The American Renaissance, another massively influential monograph appeared that provided critics with an additional framework for understanding the early American novel that had a significantly different impact than Matthiessen's book because it allowed for much more positive judgments of these texts. Focusing on the British novel, Ian Watt's The Rise of the Novel: Studies in Defoe, Richardson and Fielding (1957) argues that empiricism and liberalism paved the ground for the emergence of the first novels in early eighteenth-century England. In Watt's account, British empiricists like Bacon, Locke, Berkeley, and Hume taught aspiring novelists to appreciate the body as a privileged epistemological site, inspiring them to probe human interiority and subjective experience in their fictions. In the final analysis, Watt claims, "the novelist" and "the philosopher" share the same aim: "the production of what purports to be an authentic account of the actual experience of individuals" (2001 [1957], 27). This shift of focus from the impersonal forces of the divine cosmos to subjective experience (from Leibniz to Locke, from Bunyan to Defoe) entailed a valorization of individual experience that had its political corollary in liberalism, its social corollary in the emergence of the middle classes, and its literary corollary in the rise of the novel. Significantly, Watt's account of the rise of the British novel had a transatlantic career of its own.

While Americanists have distanced themselves from Matthiessen's narrative on account of its exceptionalism and obvious gender bias, Watt's narrative met with a more generous reception. When Cathy N. Davidson published her seminal monograph on the early American novel in 1986, her choice of subtitle pays tribute to Watt: Revolution and the Word: The Rise of the Novel in America. Davidson's argument builds on The Rise of the Novel, as she reads early American novels as negotiations of the promises and pitfalls of an emerging liberal-individualist order. In its exploration of courtship, seduction, marriage, and female friendship, Davidson argues with conviction, the early sentimental novel inquires into the palpably real yet painfully limited opportunities for self-realization that liberalism held out for women that were socialized in a patriarchal republican order which cast out fallen women and declared married women femes coverts. From Davidson's feminist perspective, early sentimental novels affirm the genuinely emancipatory potential of liberal ideology as 
they invite readers to sympathize with female characters' struggles to create lives of their own even as they highlight the pitfalls of those struggles and use the figure of the seducer to warn against liberalism's worst excesses (2004, 185-232). Davidson agrees with Emory Elliott and Jay Fliegelman that these novels ultimately stage, as the subtitle of Fliegelman's Prodigals and Pilgrims (1982) has it, a "revolution against patriarchal authority." Though only Davidson explicitly engages with Watt, these critics of the 1980s accept the broad outlines of Watt's narrative of the co-emergence of liberalism and the novel. By and large, critics of the 1990s continued to explore early novels' negotiations of tensions between the older republican-communitarian and the emergent liberal-individualist order, though with an important difference. While Davidson embraces liberalism's promise, critics such as Larzer Ziff (1991), Grantland S. Rice (1997), and Michael T. Gilmore (1994) embrace a post-Marxist narrative that values the communitarian values of the older republican order over the emerging liberal ethos that helped consolidate the young nation's capitalist regime. For them, critics like Davidson have also overstressed Locke's influence compared to that of John Trenchard and Thomas Gordon's Cato's Letters (1720-1723) - the major source of republican ideology.

While the differences between critics of the 1980s and 1990s are significant, both have contributed to a major shift in Early American Studies: from questions of aesthetics (the early American novel's lack of literary quality) to the ideological concerns (the liberalism-republicanism debate) of what Fluck (2000) labels "political criticism." In this respect at least, both groups align themselves with Watt's rather than Matthiessen's narrative as they focus not on the transatlantic transfer of literary models but on that of political ideas. Moreover, all of the critics discussed so far provide us with a transatlantic account of the early American novel that is decidedly anglo-centered. And it is this exclusive focus on British-American relations that has come under fire from the next, most recent generation of critics.

\section{2 (Post-)colonial Encounters}

Since the early 1990s, an increasing number of Americanists have begun to question the exceptionalist narratives of the Myth-and-Symbol School to which Matthiessen belonged. William Spengemann's A Mirror for Americanists: Reflections on the Idea of American Literature (1989) and A New World of Words: Redefining Early American Literature (1994) were early attempts to expand the very notion of American Literature to include not only the literary production of the United States but that of all of North and South America. Moreover, Spengemann urged his fellow scholars to include both British works and American works written during the colonial period as well as works in English affected by colonialism more generally. Such attempts to expand the scope of American Studies go well beyond earlier transatlantic accounts of British-American literary and cultural transfers as they situate U.S.-American literature in an extensive 
network of literary, cultural, and economic exchanges that connects North America, South and Central America, the African continent, and the West Indies. Once Paul Gilroy had published The Black Atlantic: Modernity and Double Consciousness (1993) ( 719 The Black Atlantic), it became almost impossible for Americanists to think about transatlantic configurations primarily in terms of either early American novelists' adaptations of Richardsonian, Godwinian, and Fieldingian literary models or Henry James's international theme ( 78 Henry James).

In American Studies, expanded notions of the Atlantic proved eminently amenable to broader reconfigurations of the field in 'transnational,' 'post-national(ist),' or 'hemispheric' terms ( $\lambda 0$ Introduction). Seminal publications such as Donald E. Pease's New Americanists: Revisionist Interventions into the Canon (1992), John Carlos Rowe's Post-nationalist American Studies (2000), Amy Kaplan's The Anarchy of Empire in the Making of U.S. Culture (2002), and Fluck, Pease, and Rowe's Re-Framing the Transnational Turn in American Studies (2011) have made powerful cases that accounts of American literature and culture which remain confined to the perimeters of the nation-state are not only ideologically dubious but also too narrow in scope to account for the imbrication of U.S. literary and cultural production in transnational networks of textual, material, and human exchange. The transnational turn in American Studies propounded by the New Americanists had a profound impact on work done in Early American Studies, where the enmeshment of North America in colonial and post-colonial constellations is perhaps even more obvious than in other corners of the discipline. The combined force of publications such as Joseph Roach's Cities of the Dead: Circum-Atlantic Performances (1996), Edward Watts' Writing and Postcolonialism in the Early Republic (1998), and Sean X. Goudie's Creole America: The West Indies and the Formation of Literature and Culture in the New Republic (2006) invites us to give transatlantic accounts of colonial and early national literary culture that are anything but anglo-centered.

To illustrate how far Early American Studies has veered away from exceptionalist assumptions, let us briefly return to Cowie's The Rise of the American Novel. Back in 1948, Cowie slated Reverend Enos Hitchcock's Memoirs of the Bloomsgrove Family (1790) in these terms: "The improving discourses on which the children dutifully sup are about as tasteless as barley water, and the anecdotes which Mr. Bloomsgrove distributes like cakes as a reward are frequently pretty musty. Moreover they were remote from American life, including such items as the 'story of a grateful Turk,' 'anecdote of a noble Venetian,' 'anecdote of a French lady,' etc.” (Cowie 1948, 17). From the perspective of transnational American Studies, Cowie's slating is misguided on two levels: not only does it privilege judgments of taste over inquiries into the cultural work literature does; in its exceptionalism, it dismisses precisely those aspects of the text that are most interesting: its Oriental and European references, which signal its embeddedness in transnational structures of meaning-making. In studies of the early American sentimental novel since the 1990s, the transnational turn has triggered a remarkable extension of the meaning of 'transatlantic.' Inquiries into the transat- 
lantic nature of the early sentimental novel are no longer confined to discussions of those (post-)colonial dynamics that can readily be observed in a novel like Rowson's Charlotte Temple: its use of a Richardsonian model; its publication on both sides of the anglophone Atlantic (in London in 1791, in Pennsylvania in 1794; $\pi 2$ The Eighteenth Century and the Literary Market Place); its negotiation of post-revolutionary anxieties in its plot, where we encounter seducers that are British officers but carry French names (Montraville, Belcour); its author's and protagonist's crossings of the Atlantic; and the author's ambivalent feelings about British-American relations as the daughter of a family that was punished for its father's loyalism during the Revolution (cf. Rust 2008, 48-103, 50-52; Davidson 2004). For critics aware of the transnational turn in American Studies, Rowson's much lesser-known Reuben and Rachel, or, Tales of Old Times (1798), a strange hybrid of historical novel, captivity narrative, frontier romance, and sentimental novel may be of greater interest than the author's by now canonical Charlotte Temple. In its sprawling historical scope - from Christopher Columbus's settlement of Peru and the suicide of a native woman raped by Columbus's deputy to Reuben asserting that his and Rachel's sons "are true-born Americans" (Rowson 2000 [1798], 368) - Reuben and Rachel tells a story about America that radically transcends its geographical and historical borders. Consider Christopher Castiglia's discussion of the text:

\footnotetext{
The oppositions that the structure of Reuben and Rachel attempts to integrate - between whites and people of color, men and women - were particularly troublesome at the time of the novel's composition, as the Founding Fathers attempted to define the place of women, Indians, and blacks in a republic in which all men nominally were created equal. Rowson presents these racial and gender divisions as basic to the American character, having been brought to the continent by the nation's first ancestor, Christopher Columbus. Hardly a benign settler and heroic adventurer, Rowson's Columbus is naive and self-serving. [...] In her treatment of Columbus, Rowson is also quick to show - again despite his protestations of innocence - the close relationship between geographical (racial) and domestic (gender) exploitation. (1995, 28-29)
}

While Castiglia focuses on Rowson's critique of women's and Native Americans' social, political, and legal discrimination throughout American history, his essay betrays a keen awareness that Rowson probes gender inequality from within a decidedly transnational framework in which not only race and gender but also colonialism and domestic imperialism are inextricably intertwined in an Atlantic network that includes England, Italy, Spain, America, and Peru. Thus, it is not only Rowson's critique of female and Indian subjugation that counteracts the reception of the book's many captivity stories as allegories of American liberation from British tyranny (Castiglia 1995, 23-26) but also its refusal to tell the history of America as an anti-colonial struggle that culminates in the creation of the nation-state. Reuben and Rachel consistently invites its readers to think beyond the confines of the nation and invites them to consider the hybridity of American experience, which becomes most prominently visible in one of the text's major characters, Columbia, who is of mixed Spanish, 
Italian, Peruvian, and English origin. Reuben and Rachel belongs to those "[s]tories of seduction-and-sentiment" that "traversed, organized, and contested the geographies of the Atlantic world, geographies that simultaneously reified, subsumed, and exceeded national identifications" (Bowers and Chico 2012, 5).

Recent transatlantic reconfigurations of Early American Studies have further enriched a field that Davidson, Fliegelman, and Elliott had put on a new and solid footing in the 1980s. Yet one should be careful not to overemphasize the differences between the republicanism-liberalism debate of the 1980s and 1990s on the one hand and the more recent transnational perspectives on the early American novel on the other. As I argue at greater length in "Early American Studies Now: A Polemic from Literary Studies” (Schweighauser 2014), what unites work in Early American Studies since the 1980s is a decisive turn from aesthetics to politics, from assessments of the quality of literary texts to inquiries into the cultural work they do. This shift is fully in line with developments in American Studies more generally and has considerably revitalized the field, both because it has made the canon of texts that are studied and taught more inclusive in social as well as generic terms and because it has allowed us to ask new, exciting questions about how these texts intervened in major social and political debates of their time.

\subsection{European Aesthetics and American Literary Production}

At the same time, the politicization of American Studies has led many a critic to abandon questions of aesthetics all too readily. Such a retreat from the aesthetic informs, for instance, religious scholar Tracy Fessenden's conviction that, while earlier scholars assigned literature to "a different, 'aesthetic' order of things," we "no longer associate literature so singularly with the aesthetic, or imagine that aesthetic concerns are absent from other kinds of writing" $(2010,185)$ and it resonates in literary scholar Russ Castronovo's assertion that

History's influence upon early American studies has had salutary effects in staving off canonizing tendencies by encouraging explorations of less strictly recognizable literary materials in ways that have opened up teaching and research to texts by and about women, new-world Africans and African Americans, and Native Americans. (2010, 487)

The same retreat from aesthetics also enables historian Cathy Matson to assert that "theorists such as Archibald Alison promoted an emotional, imagination-driven aesthetics in which beauty was not in objects themselves but rather in the mind of the spectator, thereby liberating individuals to consume not only useful goods but decorative ones as well" (2007, 788); and it is at the heart of urban historian Domenic Vitiello's conviction that the spatial turn allows historians "to move their work from the realm of style and aesthetics towards a more meaningful place in debates about 
social, economic, and urban history” (2010, 689). In these critics' understanding, a scholarly focus on "the aesthetic" is variously taken to be complicit with an elitist understanding of culture that marginalizes cultural productions by non-elites (cf. Fessenden 2010; Castronovo 2010), with divorcing the study of literature from more serious social concerns (cf. Fessenden 2010; Vitiello 2010), or with individualist bourgeois ideology (cf. Matson 2007). Paradoxically (but not contradictorily), aesthetic considerations are censured both for being apolitical and for giving expression to class-bound interests. Such conceptualizations of aesthetics as ideology seem as narrow to me as Alexander Cowie's and Herbert Ross Brown's reduction of aesthetics to the judgment of taste.

Taking aesthetics seriously means to ask what it can teach us about the nature of art and beauty on the one hand and sensuous cognition on the other. And if we do that, we begin to see a third transatlantic network that connects American literary production of the late eighteenth and early nineteenth centuries with the emergence of aesthetics as a philosophical subdiscipline since the mid eighteenth century. Such an aesthetic perspective allows us to understand that early American sentimental writers probed the very same questions in their art that early European aestheticians like Alexander Gottlieb Baumgarten, Charles Batteux, and Friedrich Schiller began to ask in their scholarly work. These questions revolve around the reliability of sensuous cognition and the nature and function of art. It was Baumgarten who coined the term "aesthetics" in his Magisterarbeit [MA thesis] Meditationes philosophicae de nonnullis ad poema pertinentibus (1735), defining it as "the science of perception" (1954 [1735], §116, 78). Baumgarten would further elaborate on the term in his two-volume Aesthetica (1750/1758), where he defines it thus: "AESTHETICA (theoria liberalium artium, gnoseologia inferior, ars pulchre cogitandi, ars analogi rationis) est scientia cognitionis sensitivae” (2007 [1750/1758], §1, I: 60). In Jeffrey Barnouw’s translation, which includes helpful glosses in square brackets: "Aesthetics, as the theory of the liberal arts, lower-level epistemology [gnoseologia inferior], the art of thinking finely [literally, beautifully, ars pulchre cogitandi], and the art of the analogy of reason [i.e., the associative or natural-sign-based capacity of empirical inference common to man and higher animals], is the science of sensuous cognition" (1988, 324; emphasis in original). For a thinker like Baumgarten, who was trained in the rationalist tradition of Christian Wolff and Johann Christoph Gottsched, declaring sensuous cognition a legitimate object of science was daring. After all, in the rationalist tradition, only reason allows for clear and distinct cognition - "claritatis intensio per distinctionem" (Baumgarten 2007 [1750/1758], §617, II: 04) - while sense perception belongs to "lower-level epistemology" in the sense that it allows us to know objects clearly but also confusedly (clara et confusa), i.e., without the conceptual distinctness of reason (Wilkinson and Willoughby 2005, xxi). Thus, from its origin in Baumgarten onward, aesthetics has been a philosophical subdiscipline that both valorizes aisthēsis (sense perception, sensation, feeling) and has serious doubts about its reliability and cognitive value. 
Returning to the original Baumgartian definition of aesthetics allows us to understand that the plots and affective force of sentimental novels raise quintessentially aesthetic questions. In these texts, sensation and feeling are the most highly valued connecting fibers of community. The narrative logic of these texts depends on the moral force of affective bonds between family members (especially mothers and daughters), female friends, and readers and characters. Aisthēsis is consistently valued over the calculating reason of seducers and what Rowson's narrator in Charlotte Temple calls “a very unfeeling world” (1987 [1791], 68). In Joanne Dobson's words, the "emotional and philosophical ethos" of sentimentalism "celebrates human connection, both personal and communal, and acknowledges the shared devastation of affectional loss" $(1997,266)$. At the same time, the downward plots of these texts make clear that any exclusive reliance on sensuous cognition, sensation, and feeling is bound to lead to destruction. Sentimental heroines like Charlotte Temple, whose "young heart glow[s] with sensibility" (Rowson 1987 [1791], 80), fall for seducers because they too fully believe what they hear and see and because they too readily take the force of their own feelings for others as proof of their love or good intentions.

Indeed, the fallibility of sense perception becomes a major problem in the affective economy of sentimentalism when feelings are dissimulated, for instance when Rowson's scheming schoolmistress Mademoiselle La Rue (nomen est omen) "let[s] fall some hypocritical tears” (1987 [1791], 30) to sway Charlotte’s opinion of her or when Major Sanford, the rake in Foster's The Coquette, throws himself at Eliza Wharton's feet to pour forth "a flood of tears" (Foster 1987 [1797], 92). In sentimental novels, such scenes, which evoke the twin specter of the dissimulation and manipulation of feelings, have a decidedly self-reflexive quality in that they address precisely those charges that contemporaneous detractors laid at the door of sentimental writers. For them, dissimulations and manipulations of feelings are not confined to the diegetic worlds of sentimental texts; they are also what these texts do: sentimental novels manipulate readers' feelings through fictional (and thus deceptive) excesses of feeling. In the words of James Watters, editor of The Weekly Magazine and an influential voice in the contemporary anti-fiction movement (Orians 1937; Martin 1969, 57-103):

\footnotetext{
Novels not only pollute the imaginations of young women, but also give them false ideas of life, which too often make them act improperly, owing to the romantic turn of thinking they imbibe from their favorite studies. They read of characters which never existed, and never can exist; and when all the wit and invention of a luxuriant fancy are stretched to paint a young man all perfection in body and mind, it is hardly possible for a girl to avoid falling in love with the phantom [...]. (Watters 1798, 184-185)
}

In exploring the fallibility of sensuous cognition and the treacherousness of feelings, then, early American sentimental novels always also explore their own modus operandi. Seen thus, sentimental writers' defenses of the truth-value and moral utility of their texts may be more than anxious responses in the face of a powerful anti-fiction movement. Prefatorial assertions such as Rowson's that she "shall feel a much higher 
gratification in reflecting on this trifling performance, than could possibly result from the applause which might attend the most elegant finished piece of literature" (Rowson 1987 [1791], 6) may express real doubts about the social function and cognitive value of the art of fiction. At the same time, Rowson does exercise her right to tell a story of seduction which she knows full well will not be read by her audience for its moral utility. She signals this when, after an extensive disquisition on Humility, Filial Piety, Conjugal Affection, Industry, Benevolence, Patience, and Hope, she has her narrator say, "I confess I have rambled strangely from my story" (Rowson 1987 [1791], 35). In exploring both sensory deception and novelists' right to fiction, early sentimental writers ask quintessentially aesthetic questions that take us to the heart of their own artistic practice, for literary texts - and works of art more generally negotiate, initiate, and participate in processes of perception and cognition. There is, then, a crucial self-reflexive element to early American sentimental writers' obsession with deception and delusion: for them, to inquire into the causes of deception and the fallibility of human sense perception is always also to inquire into the possibilities of their work in an age that still did not quite accord art the autonomy that would so confidently be bestowed on it by theorists and practitioners of Romantic art.

Aesthetics is then a central issue in early sentimental novels not only in its Baumgartian sense but also in these texts' self-reflexive interrogation of the nature and function of art. These novels participate in a transatlantic inquiry into art that had its equivalent in contemporaneous European aestheticians' attempts to identify the common features and functions shared by all the arts - from Charles Batteux's claim that imitation is the common principle that unites all forms of art in Les beaux arts réduits à un même principe (1746) to Friedrich Schiller's powerful assertion of artists' right to aesthetic semblance in his Briefe über die ästhetische Erziehung des Menschen (1795) - and to distinguish between the different arts with an eye to developing a system of the arts (Barck et al. 2000, 320). The links between American literary production of the early republic and early European philosophical reflections on art and sensuous cognition that I hint at here cannot be captured via a reception history. European treatises on art and sensuous cognition were neither widely read in the republic (cf. Schimmelmann 2007) nor did they provide models that American writers would base their narratives on. Instead, both are caught up in the process of what systems theorists call "functional differentiation": the gradual division of modern Western societies into autonomous function systems such as morality, religion, law, economics, and art that each perform a unique function for the social whole (cf. Luhmann 2000, 133; Luhmann 2013, 707-776; Luhmann 2005). The autonomization of art, which was still underway in the eighteenth and early nineteenth centuries, is part of this broader process of modernization as are early European aestheticians' attempts to define art as a distinct realm (cf. Schmidt 1989; Werber 1992).

This helps explain why both early American sentimental novels and early European aesthetic treatises are structured by pre-modern/modern tensions in the sense that they both insist that art must pay its dues to morality and religion and 
ever so tentatively carve out a separate, autonomous sphere for art. In early sentimental novels, these tensions manifest themselves in appealing stories of seduction that are advertised as socially useful; in the co-presence of literary didactics and a fledgling autonomy aesthetics; in their exploration of both the creative potential and the pathology of the imagination; and, most paradoxically, in anti-fiction diatribes within the space of fictions like The Power of Sympathy and Tabitha Gilman Tenney's sentimental-picaresque Female Quixotism (1801). In early European aesthetic treatises, pre-modern/modern tensions come to the fore in Baumgarten's exploration of an experientially grounded theory of cognition and art from within rationalism's theologically grounded metaphysics; in David Hume's decisively modern move toward an epistemological philosophy of art in essays such as "Of the Standard of Taste" that do not, however, abandon the idea that aesthetic and moral judgments are intimately connected (Gracyk 2007); and in Kant, who severs the pre-modern unity of the good, the true, and the beautiful as he assigns them to his three critiques (Bernstein 1992, 17-18) even as his exploration of beauty and the sublime in the Critique of the Power of Judgement (1790) builds bridges between social and philosophical knowledge, morality and aesthetic pleasure. What is at stake both in American literary production of the early republic and in contemporaneous aesthetic reflections on art and sensuous cognition on the other side of the Atlantic is always the degree of autonomy art may claim from the extraaesthetic realms of morality and religion. These probings of shifts in the positioning of art in the social whole are an integral part of the process of functional differentiation. To recognize this is to postulate a third, yet underexplored perspective on the early American sentimental novel's transatlanticism.

\section{A Reading: William Hill Brown's Ira and Isabella (1807)}

To probe the heuristic value of the three transatlantic perspectives outlined in the previous section, let us turn to a little-studied work of fiction: William Hill Brown's Ira and Isabella, a short novel published posthumously in 1807. Brown tells the story of the eponymous orphans who fall in love and are married but resign themselves to a relationship of chaste affection when they find out that they are brother and sister. The dénouement of the plot occurs when Ira and Isabella learn that their siblinghood is a fiction that was designed to conceal that not only Isabella but also Ira is the offspring of a pre-marital relationship. Thus, as the narrative ends, both are revealed to be bastards, with the happy effect that their matrimony is now freed of its incestuous taint. This strange tale is both firmly embedded in a transatlantic sentimental tradition and radically breaks with it, most ostensibly in its happy resolution of the kind of incestuous threat that still resulted in the deaths of both lovers in Brown's earlier, much better-known The Power of Sympathy. 
Brown's elaborate preface testifies to the transatlantic transfer of literary models, giving expression to a profound anxiety of influence caused by the colonial lag. Confessing himself "mightily troubled about a literary alternative" (1807, iii), Brown goes on to mourn that he can neither take recourse to "fairyism" (1807, iii), i.e., the rich topoi of "[g]enii and giants, magii and magicians, invincible castles and palaces of enchantment” (1807, v) that he associates with French literature nor equal the greatness of "the divine Shakespeare" (1807, vii). At the end of his extraordinary preface, Brown even adds a "SCALE OF NOVELISTS," a table in which he rates eighteen European writers on a scale of 1-20 in seven categories: "genius," "satire," "knowledge," "intelligence," "imagination," "style," and "pathos” (1807, xiii). Brown himself does not add up the numbers, but Terrence Martin has done the counting: "if one totals the points, Johnson scores 122, Swift 121, Cervantes 117, Voltaire 116, Sterne 113, and Richardson 110 - and these are certainly reasonable choices for the top places" (1959, 240). Reasonable or not, Brown's favorite six European writers belong to roughly two groups: satirists/parodists and sentimental novelists.

As far as Sterne and Richardson are concerned, Brown indeed draws liberally on the sentimental formulae of English predecessors. Though Brown's plot revolves primarily around the incest threat, the Richardsonian seduction motif plays an important role in the novel's moral universe. This becomes apparent when, fearing that Isabella will enter an incestuous relationship with Ira, Isabella's nurse Mrs. Savage warns her against indulging the sweet talk of young men in words that ring familiar from my discussion of seducers in Charlotte Temple and The Coquette: "they have always at hand a fund of fine sayings, of illusive lies, and unmeaning compliments, which are, upon every occasion, poured forth without reserve. They flatter where praise is not due, and the trade fitted to their talents, is deception" (Brown 1807, 35). At this point in the narrative, Isabella rejects the nurse's advice, but as the tale unfolds, it becomes clear that her moral steadfastness owes much to Mrs. Savage, who fills the missing part in the mother-daughter dyad that is so crucial for the educational, moral, and affective economies of sentimental novels. The novel's seducer is Florio, who advises Ira to seek pleasure elsewhere once he has been told that his wife is also his sister. Again, we find that the Richardsonian seduction motif plays a subsidiary but important function, with Florio serving as the foil against which Ira can demonstrate his moral fortitude: "According to your system," says an outraged Ira to his false friend, "I may visit the temple of obscenity, and associate myself with a daughter of prostitution, a child of infamy, the contempt and disgrace of her species. Is there no virtue extant?" (Brown 1807,88 , emphasis in original). Brown, then, looks across the Atlantic as he liberally draws on the English sentimental tradition in an attempt to weave a novel tale out of that tradition. The transformation that takes place in the journey of a literary genre across the Atlantic is perceptible in Ira's recourse to "virtue," which in an American context denotes a chief republican value that must be defended against the excesses of another transatlantic import personified by seducers like Florio: liberalism. Tensions between liberal and republican ideology are also negotiated through Isabella. 
She is clearly the stronger figure than Ira and thus gestures toward the promise of self-making that liberalism holds out for the women of the early republic: "No person breathing, of either sex, was ever blest with a more independent spirit than Isabella" (Brown 1807, 42). At the same time, it is she who most prominently extols the virtuous, i.e., selfless and patriotic heroes of republican ideology who subordinate their ambition to the public good and the prerogatives of the state: "How are we struck with the awful virtue of a Brutus or a Cato; how delighted with the more gentle, more amiable graces of a Scipio; how do we exult in the honest heart and unambitious mind of a Cincinnatus, a La Fayette, and a Washington” (Brown 1807, 72).

In its entirely conventional recourse to public figures and ideologemes of the Roman Republic, Brown's negotiation of republicanism already takes us beyond a purely anglo-centered account of the transatlantic exchange of literary genres and political ideas. In Brown's preface, his move away from an exclusive focus on British-American transfers is taken to a whole new level that invites a second kind of transatlantic reading of Ira and Isabella that more firmly situates it in its (post-) colonial contexts. In mourning the loss of "fairyism" as a viable source of topoi for American novelists, Brown does something substantially different than Charles Brockden Brown does in his preface to Edgar Huntly (1799), where he famously waves goodbye to European fashions of "[p]uerile superstitions and exploded manners, Gothic castles and chimeras" as he calls upon fellow American writers to focus on "incidents of Indian hostility, and the perils of the Western wilderness" (Brown 1984 [1799], 3) instead. Both Browns inquire into the possibility of a genuinely American literature and call for greater realism. Both also put their prefatorial statements in the service of literary nationalism - William Hill Brown when he writes that he is "not French, either in versatility or by nation" (1807, iv). Yet in the Gothic writer's account, the European models that he rejects can be fairly clearly identified: they are earlier, English variants of the same genre that he works in. In William Hill Brown's preface, this is much less straightforward, both because "[g]enii and giants, magii and magicians, invincible castles and palaces of enchantment" are hardly the stuff of the sentimental genre he writes in and because the models he waves goodbye to are identified not as English but French. Moreover, while Charles Brockden Brown relishes in his severance of transatlantic ties, William Hill Brown mourns the loss of a rich source of the literary imagination. Partly, this mourning may be tongue in cheek since in opposing "the festivity of French vivacity" to his own talent for "dealing out saturnine opinions" (1807, iv), he taps into the rhetoric of American Francophobia in the wake of the Citizen Genêt affair and the French terreur (cf. Cleves 2009). At the same time, his sadness appears genuine:

I lament the want of machinery in modern novels. But most of all I grieve for the extinction of the eastern manner: There could I have shown myself in all my glory; there could I have fired away in periods sonorous, lofty, musical and unmeaning, and proved myself a Confucius or Xixzoffou by the orientality of sentiments, grand, obscure, magnificent and incomprehensible. (Brown 1807, iv-v) 
What Brown mourns here is the unavailability of the Orientalist imagination. Now that America has severed its ties with England and created a nation-state of its own, this post-colonial early republic appears to have lost access to the European colonial imagination. In Brown's novel, this loss is recuperated only for an instant, when the actions of Doctor Joseph, one of the novel's more minor characters, are compared to "the dignified beneficence of an Ahasuerus," the Biblical King of Persia, "holding forth the life-giving sceptre to the prostrate and beautiful Esther” (1807, 47). Brown's ambivalence toward this loss must then be seen in a transatlantic context that involves not only England and the United States but also Europe and the Western world's Christian and colonial-Orientalist imagination more generally.

Moving into the third kind of transatlantic reading sketched in section 1, we find that "imagination" and "fancy" - terms that both British aestheticians and American novelists of the pre-Coleridgean era used interchangeably - are keywords in Ira and Isabella. Brown's treatment of the imagination in the diegetic world of his novel is entirely in line with that of early European aestheticians who stressed both the creative potential of the imagination and the threat that an overheated imagination poses to reason and order. Eighteenth-century aestheticians agreed that the imagination elevated human beings above animals and was the distinguishing mark of the artist. Thus, the Swiss theologian and Enlightenment philosopher Johann Georg Sulzer calls the imagination "one of the most excellent qualities of the soul" and adds that it is "the mother of all fine arts" (1771, 1: 291; my translation). But he immediately supplies a cautionary rejoinder: "Woe to the artist of excellent imagination who lacks these companions and rulers: his life will be an everlasting dream and his works will resemble more the adventures of an enchanted world than the beautiful scenes of actual nature" (1771, 1: 292; my translation). These words sum up anxieties shared by a host of eighteenth-century aestheticians, including the British empiricists. Even Joseph Addison, that most fervent champion of the creative imagination, notes that "there is not a Sight in Nature so mortifying as that of a Distracted Person, when his Imagination is troubled, and his whole Soul disordered and confused" (Addison and Steele 1810, 6: 114). In Ira and Isabella the imagination plays a similarly ambivalent role. Thus, while Brown's preface sings the praises of "lively imaginations" and "fertile fancy" (1807, iii), the plot most closely focuses on the imagination of its least trustworthy character, stressing Florio's "exquisite imagination” (1807, 84), "fanciful manner" $(1807,85)$, and "immoral imaginations" $(1807,86)$. It is in a dialogue with him that Ira spells out the dire consequences of a boundless imagination: "Tell me therefore, my friend, shall the duty I owe to my virtue, and to the social compact, be oblivioned by delusive temptation; and by a fancy wavering, incautious, and, when indulged, dangerous and ungovernable?” (Brown 1807, 91). From a systems-theoretic perspective, this shared ambivalence toward the imagination in early European aesthetics and the early American sentimental novel is one symptom of a process of functional differentiation that was to be completed only in Romantic theory and art, which, in declaring 
art autonomous, accorded the creative imagination of the genius an unconditionally productive role.

It is no coincidence that Brown's probing of the pathology of the imagination centers on his novel's seducer for it is through these characters that early sentimental novelists give expression to some of their most serious doubts concerning the vagaries of sensuous cognition and the social utility of their art. As in other early examples of the genre such as Charlotte Temple and The Coquette, Brown's seducer is engaged in the very dissimulation and manipulation of feelings that sentimental novelists are suspected of. Consider Florio's immoral advice to Ira: “Throw yourself upon the bended knee of encomiastick rapture, and pour out the incense of adulation without reserve. Never mind the truth, for hang it, Ira, when one is really in love, what signifies a few agreeable, wonder-working lies" (Brown 1807, 77-78). For detractors of novels such as James Watters and the nation's third President - who decried their "figments of fancy," which produce in their female readers nothing but "a bloated imagination, sickly judgment, and disgust towards all the real businesses of life" (Jefferson 1905 [1818], 91) - novelists do exactly what seducers do: they lie, manipulate feelings, corrupt the imagination, and kindle illicit desires. Brown taps into this anti-fiction discourse and takes it one step further when he makes his seducer an avid reader of novels: "Florio [...] had turned over more pages of novels than of Roman history" (Brown 1807, 80). Similar anti-fiction sentiments are expressed by Mr. Savage, the husband of Isabella's nurse, when he reveals that he fathered Ira illegitimately with a country girl (thus removing the incest-threat): "The seduction of innocence is the vilest subject in the world" (Brown 1807, 113), he asserts, and goes on to dissociate his late truth-telling from what novelists do: "as I am not a professed dealer in literature, I may be allowed to speak the truth” $(1807,117)$.

At first sight, Brown's incorporation of anti-fiction stances in his work of fiction seems an anxious defense strategy in the face of the anti-fiction movement. Yet a look at the novel's full title, Ira and Isabella: or the Natural Children. A Novel, Founded in Fiction. A Posthumous Work should make us pause. In opting for the unique "Founded in Fiction" instead of conventional assertions of the truth-value of fictions found in the titles of other early sentimental novels such as Brown's own The Power of Sympathy: or, The Triumph of Nature. Founded in Truth (1789) and Foster's The Coquette; or, The History of Eliza Wharton. A Novel: Founded on Fact, Brown signals that he refuses to subordinate the novelist's right to invent fictional worlds to the demands of morality and religion. Moreover, the fact that Mr. Savage, the character who denounces seduction plots, was himself a seducer counteracts any unequivocal reading of Brown's novel as a cautionary, didactic tale. In these most modern moments of his text, Brown aligns himself with the satirists and parodists that he extols alongside sentimental writers in his prefatory scale of novelists. As do so many other early American novels, Ira and Isabella oscillates between a pre-modern inclination to make literature serviceable to morality and religion and a modern assertion of the right of fiction. 
While pre-1980s criticism of the early American novel considered such pre-modern/modern tensions aesthetic flaws owed to the genre's youth and most critics since the 1980s considered them expressions of ideological tensions in the early republic, I believe it makes most sense to understand these tensions in aesthetic terms, as signs of the liminal status of an art-form on its way to modernity. In early European aesthetics, this liminal status is the most visible sign of a decisive yet ongoing shift from Cartesian rationalism to empiricism, a shift that was energized by the writings of Bacon, Locke, Berkeley, and Hume, and which laid the ground for a number of major developments in reflections on art. In its valorization of sensory cognition and of art as a specific form of cognition, the emergence of aesthetics as a philosophical subdiscipline crucially participates in that shift, and so do a number of developments within aesthetics. These include the move from an aesthetics of imitation grounded in the divine order of nature to an aesthetics of experience that valorized innovation and originality; the move from onto-theologically grounded theories of beauty that revolve around notions such as consonantia, integritas, and harmonia to more experientially grounded theories of art; and the emergence of corresponding aesthetic concepts such as sensuous cognition, taste, the imagination, genius, and the sublime that allow scholars not only to attribute to art a relative autonomy from the divinely ordered cosmos but also to study the subjective experience of both the creative process and the reception of art (cf. Beardsley 1966, 140-208; Luhmann 2000, 162, 78-79, 262-263, 271-272, 311; Barck et al.). In early American novelistic production, this liminal status comes to the fore most powerfully in irreducibly conflicted, contradictory novels like Ira and Isabella that are pre-modern in their didacticism, their claims to moral utility, and the fears they express about the unchecked imagination, and decidedly modern in their parodies of truth-telling, their embrace of the creative imagination, and their insistence on the novelist's right to invent fictional worlds. Novels such as Ira and Isabella powerfully suggest that the tensions critics have observed in early sentimental novels are as much of an aesthetic as of a social and political nature.

\section{Bibliography}

\subsection{Works Cited}

Addison, Joseph, and Richard Steele. The Spectator. 8 vols. Philadelphia: Johnson \& Warner, 1810. Askin, Ridvan, Andreas Hägler, and Philipp Schweighauser. “Introduction: Aesthetics after the Speculative Turn.” Special issue of Speculations V (2014): 6-38.

Barck, Karlheinz, Dieter Kliche, and Jörg Heininger. "Ästhetik/ästhetisch.” Ästhetische

Grundbegriffe. Ed. Karlheinz Barck, Martin Fontius, Dieter Schlenstedt, Burkhardt Steinwachs, and Friedrich Wolfzettel. Vol. 1. Stuttgart: Metzler, 2000. 308-400. 
Barnouw, Jeffrey. "Feeling in Enlightenment Aesthetics." Studies in Eighteenth-Century Culture 18 (1988): 323-342.

Batteux, Charles. Les beaux arts réduits à un même principe. Paris: Durand, 1747.

Baumgarten, Alexander G. Reflections on Poetry/Meditationes philosophicae de nonnullis ad poema pertinentibus. 1750/1758. Trans. Karl Aschenbrenner and William B. Holther. Berkeley: University of California Press, 1954.

Baumgarten, Alexander G. Ästhetik [Aesthetica]. 1735. Trans. Dagmar Mirbach. 2 vols. Hildesheim: Felix Meiner, 2007.

Beardsley, Monroe C. Aesthetics from Classical Greece to the Present: A Short History. New York: Macmillan, 1966.

Bernstein, J. M. The Fate of Art: Aesthetic Alienation from Kant to Derrida and Adorno. University Park: Pennsylvania State University Press, 1992.

Bowers, Toni, and Tita Chico. "Introduction: Atlantic Worlds in the Long Eighteenth Century: Seduction and Sentiment." Atlantic Worlds in the Long Eighteenth Century. Ed. Toni Bowers and Tita Chico. New York: Palgrave Macmillan, 2012. 1-14.

Brown, Charles B. Edgar Huntly, or Memoirs of a Sleep-Walker. 1799. Kent: Kent State University Press, 1984.

Brown, Herbert R. The Sentimental Novel in America, 1789-1860. Durham: Duke University Press, 1940.

Brown, William H. Ira and Isabella: or the Natural Children. A Novel, Founded in Fiction. A Posthumous Work. Boston: Belcher and Armstrong, 1807.

Brown, William H. The Power of Sympathy. 1789. The Power of Sympathy and The Coquette. Ed. William S. Osborne. Schenectady: New College and University Press, 1970.

Castiglia, Christopher. "Susanna Rowson's Reuben and Rachel: Captivity, Colonization, and the Domestication of Columbus." Redefining the Political Novel: American Women Writers, 1797-1901. Ed. Sharon M. Harris. Knoxville: University of Tennessee Press, 1995. 23-42.

Castronovo, Russ. "Disciplinary Panic: A Response to Ed White and Michael Drexler." Early American Literature 45.2 (2010): 485-490.

Cleves, Rachel H. The Reign of Terror in America: Visions of Violence from Anti-Jacobinism to Antislavery. Cambridge: Cambridge University Press, 2009.

Cowie, Alexander. The Rise of the American Novel. New York: The American Book Company, 1948.

Davidson, Cathy N. Revolution and the Word: The Rise of the Novel in America. Second exp. edition. Oxford: Oxford University Press, 2004.

Dobson, Joanne. "Reclaiming Sentimental Literature." American Literature 69.2 (1997): 263-288.

Fessenden, Tracy. “Religion, Literature, and Method." Early American Literature 45.1 (2010): 183-192.

Fliegelman, Jay. Prodigals and Pilgrims: The American Revolution against Patriarchal Authority, 1750-1800. Cambridge: Cambridge University Press, 1982.

Fluck, Winfried. "From Aesthetics to Political Criticism: Theories of the Early American Novel." Early America Re-Explored: New Readings in Colonial, Early National, and Antebellum Culture. Ed. Klaus H. Schmidt and Fritz Fleischman. New York: Peter Lang, 2000. 225-268.

Fluck, Winfried, Donald E. Pease, and John Carlos Rowe, eds. Re-Framing the Transnational Turn in American Studies. Hanover: Dartmouth College Press of the University Press of New England, 2011.

Foster, Hannah W. The Coquette. 1797. Introd. Cathy N. Davidson. Oxford: Oxford University Press, 1987.

Gilmore, Michael T. "The Literature of the Revolutionary and Early National Periods." The Cambridge History of American Literature. Ed. Sacvan Bercovitch and Cyrus R. K. Patell. Vol. 1: 1590-1820. New York: Cambridge University Press, 1994. 541-693. 
Gilroy, Paul. The Black Atlantic: Modernity and Double Consciousness. Cambridge: Harvard University Press, 1993.

Goethe, Johann Wolfgang von. Die Leiden des jungen Werthers. Leipzig: Weygandsche Buchhandlung, 1774.

Goudie, Sean X. Creole America: the West Indies and the Formation of Literature and Culture in the New Republic. Philadelphia: Pennsylvania University Press, 2006.

Gracyk, Ted. “Hume's Aesthetics”. 2007. The Stanford Encyclopedia of Philosophy (Summer 2007 Edition). Ed. Edward N. Zalta.

http://plato.stanford.edu/archives/sum2007/entries/hume-aesthetics/(6 May 2015).

Hume, David. "Of the Standard of Taste." The Philosophical Works of David Hume. Ed. T. H. Green and T. H. Grose. Vol. 3. London: Longman, 1874-1875.

Jefferson, Thomas. “Letter to Nathaniel Burwell, March 14, 1818.” The Works of Thomas Jefferson. Ed. Paul Leicester Ford. Vol. 9. Ney Work: G. P. Putnam’s Sons, 1905. 91.

Kant, Immanuel. Critique of the Power of Judgment. 1790. Trans. Paul Guyer and Eric Matthews. The Cambridge Edition of the Works of Immanuel Kant. Ed. Paul Guyer. Cambridge: Cambridge University Press, 2000.

Kaplan, Amy. The Anarchy of Empire in the Making of U.S. Culture. Cambridge: Harvard University Press, 2002.

Luhmann, Niklas. Art as a Social System. Trans. Eva M. Knodt. Stanford: Stanford University Press, 2000.

Luhmann, Niklas. Beiträge zur funktionalen Differenzierung der Gesellschaft. Third edition. Wiesbaden: Verlag für Sozialwissenschaften, 2005.

Luhmann, Niklas. Theory of Society. Trans. Rhodes Barrett. 2 vols. Stanford: Stanford University Press, 2012-2013.

Martin, Terrence. “William Hill Brown's Ira and Isabella.” The New England Quarterly 32.2 (1959): 238-242.

Martin, Terrence. The Instructed Vision: Scottish Common Sense Philosophy and the Origins of American Fiction. New York: Kraus Reprint, 1969.

Matson, Cathy D. Review of The Political Economy of Sentiment: Paper Credit and the Scottish Enlightenment in Early Republic Boston, 1780-1820, by Jose R. Torre. Journal of the Early Republic 27.4 (2007): 785-788.

Matthiessen, F. O. The American Renaissance: Art and Expression in the Age of Emerson and Whitman. New York: Oxford University Press, 1941.

Orians, G. H. “Censure of Fiction in American Romances and Magazines: 1789-1810.” PMLA 52.1 (1937): 195-214.

Pease, Donald E. New Americanists: Revisionist Interventions into the Canon. Durham: Duke University Press, 1992.

Petter, Henri. The Early American Novel. Columbus: Ohio State University Press, 1971.

Prévost, Antoine F. Manon Lescaut. 1731. Ed. Jean Goulemot. Paris: Librairie générale française, 2005.

Rice, Grantland S. The Transformation of Authorship in America. Chicago: University of Chicago Press, 1997.

Richardson, Samuel. Clarissa: Or, The History of a Young Lady. 1747-1748. Ed. Angus Ross. New York: Viking, 1985.

Richardson, Samuel. Pamela: Or, Virtue Rewarded. 1740-1741. Ed. Thomas Keymer. Oxford: Oxford University Press, 2008.

Roach, Joseph. Cities of the Dead: Circum-Atlantic Performances. New York: Columbia University Press, 1996. 
Rousseau, Jean-Jacques. Julie, ou la Nouvelle Héloïse. Lettres de deux amans, habitans d'une petite ville au pied des Alpes. 1761. Oeuvres complètes. Ed. Bernard Gagnebin and Marcel Raymond. Vol. 2. Paris: Bibliothèque de la Pléiade, 1960.

Rowe, John C. Post-nationalist American Studies. Berkeley: University of California Press, 2000.

Rowson, Susanna. Charlotte Temple. 1791. Ed. Cathy N. Davidson. New York: Oxford University Press, 1987.

Rowson, Susanna. Reuben and Rachel, or, Tales of Old Times. 1798. Ed. Joseph F. Bartolomeo. Peterborough: Broadview Press, 2000.

Rust, Marion. Prodigal Daughters: Susanna Rowson's Early American Women. Chapel Hill: University of North Carolina Press, 2008.

Schiller, Friedrich von. On the Aesthetic Education of Man.1795. Ed. and trans. Elizabeth M. Wilkinson and L. A. Willoughby. Oxford: Clarendon Press, 2005.

Schimmelmann, Janice G. Books on Art in Early America. New Castle: Oak Knoll Press, 2007.

Schmidt, Siegfried J. Die Selbstorganisation des Sozialsystems Literatur im 18. Jahrhundert. Frankfurt am Main: Suhrkamp, 1989.

Schweighauser, Philipp. "Book and Wax: Two Early American Media of Deception." Special issue of Philologie im Netz 5 (2012): 4-44.

Schweighauser, Philipp. "Early American Studies Now: A Polemic from Literary Studies.” Amerikastudien/American Studies 58.3 (2014): 500-505.

“Sentimentality, n.” OED Online. Oxford University Press, March 2015. http://www.oed.com/view/Entry/176061?isAdvanced=false\&result=1\&rskey=TPjzxR\& (20 May 2015).

Spengemann, William C. A Mirror for Americanists: Reflections on the Idea of American Literature. Hanover: University Press of New England, 1989.

Spengemann, William C. A New World of Words: Redefining Early American Literature. New Haven: Yale University Press, 1994.

Sterne, Laurence. A Sentimental Journey and Other Writings. 1768. Ed. Ian Jack and Tim Parnell. Oxford: Oxford University Press, 2008.

Sulzer, Johann G. Allgemeine Theorie der schönen Künste in einzeln, nach alphabetischer Ordnung der Kunstwürter auf einander folgenden, Artikeln abgehandelt. 2 vols. Leipzig: Weidmann und Reich, 1771-1774.

Tenney, Tabitha G. Female Quixotism. 1801. Ed. Jean Nienkamp and Andrea Collins. Oxford: Oxford University Press, 1992.

Trenchard, John, and Thomas Gordon. Cato's Letters: or, Essays on Liberty, Civil and Religious, and Other Important Subjects. 1720-1723. Ed. Ronald Hamowy. 2 vols. Indianapolis: Liberty Fund, 1995.

Vitiello, Domenic. Review of City Building on the Eastern Frontier: Sorting the New NineteenthCentury City, by Diane Shaw. Journal of the Early Republic 25.4 (2010): 689-692.

Watt, Ian. The Rise of the Novel: Studies in Defoe, Richardson and Fielding. 1957. Berkeley: University of California Press, 2001.

Watters, James. "Character and Effects of Modern Novels." The Weekly Magazine of Original Essays, Fugitive Pieces, and Interesting Intelligence. Philadelphia: H. Maxwell, March 10, 1798. 184-185.

Watts, Edward. Writing and Postcolonialism in the Early Republic. Charlottesville: University Press of Virginia, 1998.

Weiner, E. S. C., and John A. Simpson. The Oxford English Dictionary. Second edition. Oxford: Clarendon Press, 1989.

Werber, Niels. Literatur als System: Zur Ausdifferenzierung literarischer Kommunikation. Opladen: Westdeutscher Verlag, 1992. 
Wilkinson, Elizabeth M., and L. A. Willoughby. "Introduction." On the Aesthetic Education of Man. By Friedrich von Schiller. Ed. and trans. Elizabeth M. Wilkinson and L. A. Willoughby. Oxford: Clarendon Press, 2005. xi-cxcvi.

Ziff, Larzer. Writing in the New Nation: Prose, Print, and Politics in the Early United States. New Haven: Yale University Press, 1991.

\subsection{Further Reading}

Beardsley, Monroe C. Aesthetics from Classical Greece to the Present: A Short History. New York: Macmillan, 1966.

Clark, Michael P., ed. Revenge of the Aesthetic: The Place of Literature in Theory Today. Berkeley: University of California Press, 2000.

Dillon, Elizabeth M. “Sentimental Aesthetics.” American Literature 76.3 (2004): 495-523.

Mirbach, Dagmar. "Einführung: Zur fragmentarischen Ganzheit von Alexander Gottlieb Baumgarten's Aesthetica (1750/58)." Ästhetik [Aesthetica]. By Alexander Gottlieb Baumgarten. Trans. Dagmar Mirbach. Vol.1. 2 vols. Hildesheim: Felix Meiner, 2007. xv-lxxx.

O'Donnell, Catherine. "Literature and Politics in the Early Republic: Views from the Bridge." Journal of the Early Republic 30.2 (2010): 272-292.

Rowe, John C. "Transnationalism and American Studies." Encyclopedia of American Studies. Ed. Miles Orvell. Baltimore: Johns Hopkins University Press, 2011.

Samuels, Shirley. The Culture of Sentiment: Race, Gender, and Sentimentality in Nineteenth-Century America. New York: Oxford University Press, 1992.

Slauter, Eric. "History, Literature, and the Atlantic World." Early American Literature 43.1 (2008): 153-186.

Summers, David. "Origins of Aesthetics: History of Aisthēsis." Encyclopedia of Aesthetics. Ed. Michael Kelly. Vol. 3. New York: Oxford University Press, 1998. 428-432.

Tompkins, Jane. Sensational Designs: The Cultural Work of American Fiction, 1790-1860. 0xford: Oxford University Press, 1985. 